\title{
RGS22 wt Allele
}

National Cancer Institute

\section{Source}

National Cancer Institute. RGS22 wt Allele. NCI Thesaurus. Code C114443.

Human RGS22 wild-type allele is located in the vicinity of $8 q 22.2$ and is approximately 170

$\mathrm{kb}$ in length. This allele, which encodes regulator of G-protein signaling 22 protein, is involved in the positive regulation of GT Pase activity and the negative regulation of receptor signaling. 